\title{
Procedimentos para determinação e análise da rentabilidade dos produtos em micro e pequenas empresas industriais alimentícias
}

\author{
Alex Eckert \\ Mestre pela UCS \\ alex.eckert@bol.com.br \\ Roberto Biasio \\ Doutor pela UCS \\ rbiasio@commcenter-rs.com.br \\ Marlei Salete Mecca \\ Doutora pela UCS \\ msmecca@gmail.com \\ Fabiana Pacheco da Luz \\ Bacharel Contábil pela UCS \\ fabiana.pacheco@pommier.com.br
}

\section{Resumo}

No atual mercado competitivo, conhecer a rentabilidade dos produtos oferecidos é peça chave para o sucesso de uma empresa. Porém, para chegar neste percentual é preciso seguir alguns procedimentos. De acordo com este contexto, a pesquisa efetuada tem o objetivo de evidenciar os procedimentos a serem seguidos para determinação e análise da rentabilidade dos produtos em micro e pequenas empresas alimentícias e, para alcançar este objetivo, o estudo mostra inicialmente um levantamento do referencial teórico relacionado ao tema. A pesquisa é de tipologia exploratória, onde foi feito um estudo de caso buscando analisar a rentabilidade dos produtos da empresa estudada e também identificar a viabilidade ou não da empresa tornar-se formal. Para o levantamento dos dados foi feito um acompanhamento de todo processo produtivo dos produtos estudados. Com o estudo conclui-se que micro e pequenas empresas têm papel fundamental na economia brasileira e mundial, porém estas precisam estar preparadas para sobreviver às dificuldades do mercado. Diante disso, o estudo efetuado mostrou que na atual situação o empreendimento possui boa rentabilidade de seus produtos e ao tornar-se formal, a melhor opção, no atual momento, é o enquadramento como Empreendedor Individual. A opção do Simples Nacional se torna favorável somente após aumento de faturamento, pois com a formalização a empresa passa a ter algumas despesas fixas que até então não existiam.

Palavras-chave: Micro e pequena empresa. Contabilidade de Custos. Margem de contribuição. Lucro. Rentabilidade. Viabilidade de formalização. 


\section{Introdução}

No atual mercado brasileiro, vem crescendo cada vez mais o número de micro e pequenas empresas. Segundo o boletim estatístico de micro e pequenas empresas do Sebrae (2005), entre 1996 e 2002 microempresas evoluíram de 2.956.749 para 4.605.607, com crescimento acumulado de $55,8 \%$. Já as pequenas empresas aumentaram de 181.115 para 274.009, com crescimento de 51,3\%. Microempresas aumentaram o seu percentual de participação no total das empresas de $93,2 \%$ em 1996, para 93,6\% em 2002. Com estes dados pode-se observar a importância significativa das micro e pequenas empresas na economia do Brasil.

As pequenas empresas não são pilares de sustentação, somente no Brasil, segundo Longenecker et al. (1998, p. 34):

[...] as pequenas empresas contribuem inquestionavelmente para o bem estar da nação. [...] Elas oferecem contribuições excepcionais, na medida em que fornecem novos empregos, introduzem inovações, estimulam a competição, auxiliam as grandes empresas e produzem bens e serviços com eficiência.

Atualmente, as micro e pequenas empresas não só têm que enfrentar a concorrência entre elas, mas também, elas devem estar preparadas para enfrentar a concorrência com as grandes empresas. Já que, com a globalização do mercado, não existem mais fronteiras que protegem mercados, seja de grandes, médias, pequenas ou mesmo micro empresas.

Muitas empresas, principalmente as micro empresas, acabam estabelecendo os preços de seus produtos seguindo os preços praticados pelo mercado. E por não terem uma estrutura de custos que lhe permitem avaliar o retorno que esses preços geram, simplesmente desconhecem se os preços praticados geram alguma rentabilidade. Esse cenário é muito propício para o fechamento de muitas empresas, algo que é muito prejudicial, tanto para os empreendedores, como para a economia brasileira. Pesquisar alternativas que possam contribuir para a melhoria da gestão dessas empresas, sem dúvida, é algo muito importante.

Isso evidencia que os empresários precisam ter disponíveis informações detalhadas, que lhes permitam gerar análises minuciosas de seus produtos. Com as análises detalhadas, o empreendedor tem maior poder de negociação, sabe até onde pode reduzir os preços e o quanto cada venda irá lhe proporcionar de rentabilidade.

Diante disso, surgiu o interesse em levantar quais os procedimentos/etapas a serem seguidos para micro empresas terem condições de determinar a rentabilidade de seus produtos. Para fins de estudo, definiu-se que será desenvolvido um estudo de caso, evidenciando quais os procedimentos/etapas necessários para a determinação da rentabilidade dos produtos. Por isso, escolheu-se uma micro indústria do setor de alimentos.

Com base na delimitação do tema de pesquisa proposto, a questão de pesquisa para o estudo é: Quais os procedimentos a serem seguidos para a determinação e análise da rentabilidade dos produtos em micro e pequenas empresas no setor das indústrias de alimentos?

Essa pesquisa tem como característica a tipologia exploratória. Sobre pesquisa exploratória, Gil (1999, p. 43) coloca que "têm como finalidade desenvolver, esclarecer e modificar conceitos e ideias, tem em vista, a formulação de problemas mais precisos ou hipóteses pesquisáveis para estudos posteriores".

Quanto aos procedimentos, a pesquisa será realizada através estudo de caso. Para o estudo de caso, Cervo e Bervian (2002, p. 67) afirmam que "é a pesquisa sobre um determinado indivíduo, família, grupo ou comunidade que seja representativo do seu universo, para examinar aspectos variados de sua vida". 


\section{Micro e pequenas empresas}

Atualmente, as micro e pequenas empresas apresentam papel primordial na economia brasileira e mundial. Pois, segundo DIEESE (2011), no período de 2002 a 2010 o crescimento médio de MPEs foi de 3,7\% a.a, com isso, em 2010 micro e pequenas empresas correspondem a $99 \%$ das empresas.

Para Longenecker (1998), o fato das pequenas empresas apresentarem um crescimento acelerado, algumas razões não estão claras, por isso, acredita-se que alguns fatores, estão contribuindo para este crescimento rápido. Dentro desses fatores pode ser destacado: novas tecnologias, pois as mesmas podem permitir uma eficiente produção em uma escala menor que antes e também maior flexibilidade, item que favorece as pequenas empresas.

Segundo Chér (1990), em atividades que necessitam habilidades ou serviços especializados, as pequenas empresas apresentam melhor desempenho, com isso as mesmas levam vantagem sobre as grandes organizações.

Com as informações apresentadas, nota-se que as micro e pequenas empresas não são importantes só para economia brasileira e mundial, mas também responsáveis pela geração de novos empregos. A importância das mesmas não para por aí, pois segundo Kruglianslas (1996) apud Thomé (2008, p. 29) o grande número de MPEs trás "uma menor concentração de mercado e induz à melhor distribuição de renda, favorecendo a estabilidade social e política".

\section{Determinação do custo dos produtos}

Para Martins (2009, p. 25) custo é "gasto relativo a bem ou serviço utilizado na produção de outros bens ou serviços". As despesas, o mesmo define como "bem ou serviço consumido direta ou indiretamente para a obtenção de receitas". Porém, na prática, ainda existe muita dificuldade no momento da separação de custos e despesas, por isso, Martins (2009), criou algumas regras básicas que podem ser seguidas, que são:

- não devem ser rateados valores irrelevantes dentro dos gastos totais da empresa;

- não devem também ser rateados valores relevantes, porém repetitivos a cada período, que numa eventual divisão teriam sua parte maior considerada como despesa, pois os mesmos tornam-se despesa por seu montante integral;

- devem ser evitados para apropriação aos custos valores cujo rateio é arbitrário.

$\mathrm{Na}$ estrutura de custos, os mesmos devem ser classificados como: quanto as variações da produção o custo será fixo ou variável, quanto a alocação será direto ou indireto. Segundo Martins (2009) custos diretos, são os custos que podem ser diretamente identificados no produto (ex. mão de obra direta). Já, os custos indiretos não são identificados em um primeiro momento, estes são alocados (ex. mão de obra indireta). Para custos fixos e variáveis Martins (2009) afirma que custos fixos são os custos que as empresas têm todo mês, independente do volume de fabricação (ex. aluguel fábrica). Custos variáveis são os custos que variam de acordo com o volume produzido (ex. matéria-prima).

Após a separação correta dos custos de um produto, é preciso identificar como será feita a apropriação dos custos, ou seja, qual o método de custeio a ser utilizado. Pois, segundo Martins (2009, p. 37) "custeio significa apropriação de custos".

\section{Formação do preço de venda}

No atual mercado competitivo o preço de venda ainda é uma das portas de entrada para conquistar novos clientes. Por isso, 
empresários devem estar atentos aos preços aplicados, pois a empresa precisa apresentar resultados positivos para sua continuidade. Por isso, Martins (2009), coloca que para administrar o preço de venda, é necessário conhecer o custo do produto. Além do custo, é preciso saber os preços de produtos concorrentes, o grau de elasticidade da demanda, os preços de produtos substitutos e etc., claro que todos esses fatores dependem também do tipo de mercado que a empresa está inserida.

O tipo de mercado que a empresa está inserida, varia a sua liberdade na fixação dos preços de venda. Apesar de muitas empresas definirem os seus preços de venda pelo mercado, Crepaldi (2002, p. 259) afirma "que o mercado não é nem deve ser o único caminho para definição de preços, mas é importante ter os preços compatíveis com o mercado".

\section{Margem de contribuição}

A margem de contribuição é uma das principais ferramentas na análise dos produtos, pois a mesma fornece informações completas que permitem o empreendedor decidir quais produtos deve dar mais foco, qual produto que mais contribui. Padoveze (2009, p. 377) coloca que:

O modelo de decisão da margem de contribuição é o modelo decisório fundamental para gestão dos resultados da empresa, seja em termos de rentabilidade dos produtos, atividades, áreas de responsabilidade, divisões, unidades de negócios ou da empresa como um todo.

A margem de contribuição pode ser determinada como unitária e/ou total. Segundo Martins (2009, p. 179) margem de contribuição unitária "[...] é a diferença entre o preço de venda e o Custo Variável de cada produto; é o valor que cada unidade efetivamente traz à empresa de sobra entre sua receita e o custo que de fato provocou e que lhe pode ser imputado sem erro". Para Martins (2009) margem de contribuição total é a margem de contribuição unitária, multiplicada pela quantidade vendida e somada à dos demais.

\section{Rentabilidade}

Dentre vários fatores determinantes para o sucesso de uma empresa, pode ser destacada a análise da rentabilidade. Segundo Padoveze (2009, p. 444) "uma rentabilidade adequada continuadamente é, possivelmente, o maior indicador de sobrevivência e sucesso da empresa".

Padoveze (2003) afirma que o método de custeamento dos produtos é a base conceitual para a análise de rentabilidade, pois ao atribuir um único método, que não seja o adequado, pode-se levar a decisões equivocadas, e até perigosas para a empresa.

A análise da rentabilidade dos produtos pode ser unitária ou total. Quanto à análise unitária dos produtos Padoveze (2003) coloca que é uma análise simples, pois com o método de apuração do custo unitário, basta analisar o custo unitário obtido com o preço de venda. $\mathrm{Na}$ análise total dos produtos, $\mathrm{o}$ mesmo complementa que o próximo procedimento é analisar as informações dos custos unitários, associados aos gastos fixos totais, em conjunto com os volumes produzidos ou vendidos, esperados ou reais, em um determinado período, normalmente um ano. Segundo o autor, a rentabilidade dos produtos pode ser calculada de duas formas, que são (1) sobre o preço de venda e (2) sobre o custo de compra/produção. A primeira evidencia a rentabilidade que a margem gera em relação ao preço de venda (PV) e tem por objetivo informar o quanto (\%) do preço de venda sobra para a empresa custear seus custos fixos, suas despesas fixas e depois disso passar 
a gerar lucro. Já a segunda tem por objetivo evidenciar o quanto (\%) o produto tem gerado de margem em relação ao custo do produto, seja ele de produção variável ou de compra. Em função de não ser considerado o custo fixo de produção, essa forma é mais usada no comércio, onde não existem custos fixos, sendo que, a forma mais usada, tanto no comércio como na indústria, é a primeira (retorno sobre o preço de venda).

\section{Estudo de caso}

\subsection{Contextualização do empreendimento}

O empreendimento estudado é uma indústria de pães e biscoitos e a sua atividade é informal, exercida de forma familiar (mãe e um filho). As vendas dos produtos acontecem desde 1995, sendo que, o processo produtivo é executado pelos dois membros da família e acontece na própria residência, onde existe um espaço específico para produção e armazenamento do estoque. A compra dos materiais utilizados no processo produtivo acontece em mercados populares, distribuidores sempre visando comprar produtos de qualidade e por menores preços. Para fins de pesquisa, visando preservar a identidade do empreendimento estudado, ele será identificado pelo nome de "Pão \& Biscoito".

O processo produtivo da Pão e Biscoito ocorre em tempo parcial (em função da demanda atual seria inviável trabalhar em tempo integral), sendo que parte dele é realizado de forma manual e a outra parte é realizado com o auxílio de máquinas. Mesmo considerando que a empresa possui um pequeno número de máquinas, elas são muito importantes, agilizando alguns processos que seriam morosos se fossem feitos de forma manual e outros processos que só são exequíveis com o uso de equipamentos (ex. forno). A Pão e
Biscoito não possui funcionários registrados, sendo que, para fins desse estudo, no levantamento de custos foi considerado que o filho, mesmo não sendo funcionário, ele será considerado como se fosse. Já em relação a mãe, como ela é proprietária do empreendimento e a sua remuneração vem dos lucros, então não foi considerado nenhum custo em relação ao seu trabalho, sendo que, ao final será avaliada qual será a remuneração que a proprietária recebe via lucro.

Grande parte da produção da Pão e Biscoito tem como destino clientes fixos, sendo que, os pedidos são feitos sob encomenda. Entre os clientes da Pão e Biscoito, existem alguns que são consumidores finais (conhecidos da família), mas a maioria das vendas são para clientes que revendem os produtos.

Em relação aos controles internos, identificou-se que não existe nenhum controle em relação aos custos e processos de produção, consequentemente, a Pão e Biscoito não tem nenhuma ideia de qual é a rentabilidade dos seus produtos. Situação que tem gerado dúvidas a proprietária quanto a viabilidade ou não de expandir a produção (buscando novos clientes), bem como da viabilidade ou não de tornar a atividade formal (constituir uma empresa).O simples fato de não saberem qual é o real resultado atual tem preocupado muito os proprietários.

\subsection{Cálculo do custo dos produtos}

A primeira tarefa foi identificar quais os produtos que a Pão \& Biscoito produz. Em seguida foi realizado o levantamento de quais os materiais que são utilizados na fabricação de cada produto, bem como, quais são as atividades desenvolvidas no processo de fabricação. Com base nessas informações foram elaboradas planilhas, visando determinar os custos de cada produto. Para fins dessa coleta, foi realizado o acompanhamento da produção de um lote de cada tipo de produto, 
onde se identificou quais os materiais utilizados e os processos produtivos envolvidos. Durante a observação foi constatado que as tarefas são realizadas por duas pessoas: um funcionário (filho) e a proprietária (mãe). Para fins de custos, como já foi informado, os custos de mão de obra direta, só será considerado o custo do funcionário, visto que, a proprietária não têm pró-labore, sendo que, a remuneração dela é proveniente dos resultados. Outro ponto importante a ser informado é que, pelo fato da fábrica estar situada em uma sala da casa da proprietária, no cálculo do custo do produto não foi incluso o custo fixo de aluguel. Essa decisão foi tomada em função de que a sala utilizada não teria como gerar qualquer rendimento adicional para os proprietários, ou seja, não representa nenhum custo de oportunidade. No entanto, se o negócio crescer e tiver que buscar um local maior, certamente, o custo do aluguel deverá ser considerado.

Para fins de levantamento dos custos, entendeu-se que o mais adequado seria dividir esse processo em três etapas (uma para cada tipo de custo), de forma a evidenciar os valores separados para cada tipo de custo: matéria-prima, mão de obra direta e custos indiretos.

\subsection{Determinação do custo da matéria-prima}

Inicialmente foi identificada a quantidade (kg, un, lt, dz) das matérias-primas consumidas na fabricação de cada produto e foram anotadas na planilha de custos de cada produto. Em seguida foram levantados os custos de cada unidade dos materiais utilizados no processo de produção (tabela 2). Com base nessas duas informações (quantidade do material aplicado e o seu respectivo custo por unidade), procedeu-se a multiplicação das quantidades pelo custo unitário de cada ma- terial e com isso foi obtido o custo total de cada material e com a soma deles, encontrou-se o custo total dos materiais diretos empregados em cada produto.

Tabela 2: Custo dos materiais diretos aplicados

\begin{tabular}{l|l|r}
\hline Materiais diretos (matéria -prima) & Unid. & Custo Unit. \\
\hline Farinha de trigo & KG & 1,19 \\
\hline Farinha de milho & KG & 1,43 \\
\hline Maisena & KG & 1,76 \\
\hline Açúcar & KG & 1,93 \\
\hline Fermento & KG & 19,50 \\
\hline Manteiga & KG & 6,00 \\
\hline Sal & KG & 0,93 \\
\hline Gordura & LT & 2,90 \\
\hline Ovos & DZ & 3,00 \\
\hline Água & LT & 0,45 \\
\hline Leite & LT & 1,79 \\
\hline Sal amoníaco & KG & 3,80 \\
\hline Embalagem & UND & 0,05 \\
\hline
\end{tabular}

Fonte: Produção dos autores

\subsubsection{Determinação do custo da mão de obra direta}

O cálculo do custo da mão de obra direta foi determinado considerando-se o valor mensal do salário e os encargos trabalhistas devido ao funcionário, considerando-se que a atividade da empresa ocorre em meio turno. Para esse fim, mesmo que o funcionário não te o registro funcional formalizado, para fins de determinação do custo, julgou-se ser adequado considerar todos os encargos trabalhistas devidos (não foram considerados os encargos previdenciários, uma vez que, mesmo na hipótese da Pão e Biscoito passar a ser um empreendimento formal, tributada 
pelo Simples, não teria esse encargo). O custo total mensal da mão de obra direta, considerando-se apenas um funcionário, em turno parcial, é de R\$645,00, conforme tabela 3.

Tabela 3: Custo mensal da mão de obra direta

\begin{tabular}{lc}
\hline Descrição do custo & Valor mensal \\
\hline Salário & $\mathrm{R} \$ 500,00$ \\
FGTS 8,00\% & $\mathrm{R} \$ 40,00$ \\
Provisão Férias $1 / 12$ avos $+1 / 3$ const. & $\mathrm{R} \$ 55,56$ \\
FGTS s/ Prov. Férias $1 / 12$ avos $+1 / 3$ & \\
Const. & $\mathrm{R} \$ 4,44$ \\
Provisão $13^{\circ}$ Salário & $\mathrm{R} \$ 41,67$ \\
FGTS s/ Prov. $13^{\circ}$ salário $-8,00 \%$ & $\mathrm{R} \$ 3,33$ \\
Total & $\mathrm{R} \$ 645,00$ \\
\hline
\end{tabular}

Fonte: Produção dos autores

A tabela 4 evidencia o tempo necessário que cada produto utiliza por tipo de atividade, o total dos tempos das atividades utilizadas em cada produto e a quantidade de lotes produzidos, em média, por mês de cada produto. Também apresenta o total do tempo necessário, mensalmente, para produzir os lotes de cada produto previsto, sendo que o total de todos os tempos é de 102,16 horas. Pode-se observar que existem dois produtos que requerem um volume grande de tempo (biscoitos caramelado e colonial), por outro lado existem dois que necessitam um tempo bem menor (pão de milho e pão de trigo).

Com base no custo total mensal da mão de obra direta ( $\mathrm{R} \$ 645,00)$ e no total mensal do tempo das atividades $(102,16 \mathrm{~h})$, foi possível determinar o custo da mão de obra por hora, sendo ele de R \$6,31 ( $\$$ \$ 645,00 / 102,16 h). Uma vez determinado o custo da mão de obra por hora, para determinar o custo de cada atividade desenvolvida na produção de cada produto, basta multiplicar esse valor pelo tempo necessário para cada atividade, sendo que, a soma dos custos totais de cada atividade representa o custo total de mão de obra direta necessário para a produção do lote de cada produto.

Tabela 4: Tempos de mão de obra das atividades produtivas.

\begin{tabular}{|c|c|c|c|c|c|}
\hline Procedimentos & $\begin{array}{c}\text { Rosca de } \\
\text { milho }\end{array}$ & $\begin{array}{c}\text { Biscoito } \\
\text { caramelado }\end{array}$ & $\begin{array}{l}\text { Biscoito } \\
\text { colonial }\end{array}$ & $\begin{array}{l}\text { Pão de } \\
\text { milho }\end{array}$ & $\begin{array}{c}\text { Pão de } \\
\text { trigo }\end{array}$ \\
\hline Amassar & 0,25 & 1,00 & 1,00 & 0,50 & 0,30 \\
\hline Modelar & 0,50 & 1,00 & 0,50 & 0,50 & 1,50 \\
\hline Assar & 0,50 & 1,50 & 0,50 & 0,00 & 0,00 \\
\hline Caramelar & 0,00 & 1,00 & 0,00 & 0,00 & 0,00 \\
\hline Embalar & 0,33 & 0,50 & 0,50 & 0,25 & 0,25 \\
\hline $\begin{array}{l}\text { Total de horas } \\
\text { trab.por lote }\end{array}$ & 1,58 & 5,00 & 2,50 & 1,25 & 2,05 \\
\hline Lotes por mês & 12 & 8 & 12 & 4 & 4 \\
\hline $\begin{array}{l}\text { Total de horas } \\
\text { trab.por mês }\end{array}$ & 18,96 & 40,00 & 30,00 & 5,00 & 8,20 \\
\hline
\end{tabular}

Fonte: Produção dos autores 
7.3.2 Determinação do valor dos custos indiretos.

No levantamento dos custos, realizado na Pão e Biscoito, só foram identificados três custos indiretos: depreciação dos equipamentos, a energia elétrica consumida nos equipamentos e o gás usado no fogão. Em função do fato de ambos terem uma estreita relação com os equipamentos, então se entendeu que a forma mais adequada para a sua distribuição deveria ser feita com base no tempo das atividades que utilizam os referidos equipamentos. Para isso foi necessário levantar uma média do total de horas trabalhadas, mensalmente, de cada equipamento, conforme evidenciado na tabela 5 .
O custo de depreciação de cada equipamento foi estabelecido considerando o custo de aquisição dos mesmos e uma vida útil de 10 anos (120 meses), conforme evidenciado na tabela 6. Em virtude do fogão a gás utilizado ser muito antigo e também usado para atividades domésticas não está sendo considerada a depreciação do mesmo.

Para fins de determinação do custo de energia elétrica foi identificado o consumo em $\mathrm{kwv} / \mathrm{h}$, previsto para cada equipamento, em seu respectivo manual. $\mathrm{O}$ custo unitário por $\mathrm{kwv} / \mathrm{h}$ consumido foi obtido junto à conta de energia elétrica, paga à companhia que fornece a energia. Com base nessas duas informações e na quantidade de tempo de uso do equipamento, nas atividades produtivas,

Tabela 5: Total de horas trabalhadas dos equipamentos

\begin{tabular}{l|c|c|c|c|c|c}
\hline Equipamento & $\begin{array}{c}\text { Rosca de } \\
\text { Milho }\end{array}$ & $\begin{array}{c}\text { Biscoito } \\
\text { Caramelado }\end{array}$ & $\begin{array}{c}\text { Biscoito } \\
\text { Colonial }\end{array}$ & $\begin{array}{c}\text { Pão de } \\
\text { Milho }\end{array}$ & $\begin{array}{c}\text { Pão de } \\
\text { trigo }\end{array}$ & Total \\
\hline Balança & 3,00 & 2,00 & 3,00 & 1,00 & 1,00 & $\mathbf{1 0 , 0 0}$ \\
Batedeira & 0,96 & 2,00 & 3,00 & 0,00 & 0,00 & $\mathbf{5 , 9 6}$ \\
Forno & 12,00 & 8,00 & 7,20 & 2,40 & 2,00 & $\mathbf{3 1 , 6 0}$ \\
Sovadeira 1 & 0,00 & 0,00 & 6,00 & 0,00 & 4,00 & $\mathbf{1 0 , 0 0}$ \\
Sovadeira 2 & 3,00 & 5,28 & 7,92 & 0,00 & 2,00 & $\mathbf{1 8 , 2 0}$ \\
\hline Total de horas trabalhadas dos equipamentos
\end{tabular}

Fonte: Produção dos autores

Tabela 6: Custo da depreciação por hora

\begin{tabular}{l|r|r|r|r}
\hline Equipamento & $\begin{array}{c}\text { Valor do } \\
\text { Equipamento }\end{array}$ & $\begin{array}{r}\text { Valor mensal } \\
\text { da depreciação }\end{array}$ & $\begin{array}{r}\text { No de horas } \\
\text { mensais } \\
\text { trabalhadas }\end{array}$ & $\begin{array}{r}\text { Custo de } \\
\text { depreciação } \\
\text { por hora }\end{array}$ \\
\hline Balança & 400,00 & 3,33 & 10,00 & 0,3333 \\
Batedeira & 450,00 & 3,75 & 5,96 & 0,6292 \\
Forno & $2.350,00$ & 19,58 & 31,60 & 0,6197 \\
Sovadeira 1 & 700,00 & 5,83 & 10,00 & 0,5833 \\
Sovadeira 2 & $1.000,00$ & 8,33 & 18,20 & 0,4579 \\
\hline
\end{tabular}

Fonte: Produção dos autores 
foi possível determinar o custo total de cada atividade. Para isso foi multiplicado o tempo usado, em $\mathrm{kwv} / \mathrm{h}$ utilizado por produto pelo custo de cada $\mathrm{kwv} / \mathrm{h}$, informado na conta de energia elétrica. Após o levantamento dos custos diretos e indiretos, a etapa seguinte foi, com base nas informações disponíveis, determinar o custo de cada produto. Para isso elaborou-se uma tabela, evidenciando o custo de cada item (seja material, mão de obra direta ou custo indireto), de forma a demonstrar o custo despendido para cada lote de produto elaborado e, ao final, dividindo o custo total do lote pelo total de kg/und pro- duzidos, para obter o custo unitário por quilo ou unidade do referido produto.

Para fins de evidenciação dos custos de produção, objetivando sintetizar a apresentação, todos os produtos estão evidenciados em uma única tabela, mesmo que alguns produtos não utilizassem todas as atividades de elaboração que a empresa desenvolve. Situação semelhante aos materiais diretos. Sendo assim, quando a quantidade não for informada significa que o referido material e/ou atividade não é utilizada para o respectivo produto.

Tabela 7: Custo de fabricação dos produtos

\begin{tabular}{|c|c|c|c|c|c|c|c|c|c|c|c|c|}
\hline \multicolumn{3}{|l|}{ PRODUTO } & \multicolumn{2}{|c|}{$\begin{array}{l}\text { Rosca } \\
\text { de milho }\end{array}$} & \multicolumn{2}{|c|}{$\begin{array}{l}\text { Biscoito } \\
\text { caramelado }\end{array}$} & \multicolumn{2}{|c|}{$\begin{array}{l}\text { Biscoito } \\
\text { caramelado }\end{array}$} & \multicolumn{2}{|l|}{$\begin{array}{l}\text { Pão de } \\
\text { milho }\end{array}$} & \multicolumn{2}{|l|}{$\begin{array}{l}\text { Pão de } \\
\text { trigo }\end{array}$} \\
\hline $\begin{array}{l}\text { Descrição do } \\
\text { Custo }\end{array}$ & Unid. & $\begin{array}{l}\text { Custo } \\
\text { Unit. }\end{array}$ & Quant. & $\begin{array}{l}\text { Custo } \\
\text { Total }\end{array}$ & Quant. & $\begin{array}{l}\text { Custo } \\
\text { Total }\end{array}$ & Quant. & $\begin{array}{l}\text { Custo } \\
\text { Total }\end{array}$ & Quant. & $\begin{array}{l}\text { Custo } \\
\text { Total }\end{array}$ & Quant. & $\begin{array}{l}\text { Custo } \\
\text { Total }\end{array}$ \\
\hline MATERIAIS & & & & 20,64 & & 33,51 & & 27,67 & & 10,66 & & 11,66 \\
\hline Farinha de trigo & $\mathrm{Kg}$ & 1,19 & 3,00 & 3,57 & 7,00 & 8,33 & 7,00 & 8,33 & 2,00 & 2,38 & 5,00 & 5,95 \\
\hline Farinha de milho & $\mathrm{Kg}$ & 1,43 & 3,00 & 4,29 & & - & & - & 2,00 & 2,86 & & - \\
\hline Maisena & $\mathrm{Kg}$ & 1,76 & & & 0,30 & 0,53 & 0,30 & 0,53 & & - & & - \\
\hline Açúcar & $\mathrm{Kg}$ & 1,93 & 2,50 & 4,83 & 6,00 & 11,58 & 3,00 & 5,79 & 0,77 & 1,49 & 0,42 & 0,81 \\
\hline Fermento & $\mathrm{Kg}$ & 19,50 & & & & & & & 0,05 & 0,98 & 0,02 & 0,29 \\
\hline Manteiga & $\mathrm{Kg}$ & 6,00 & 0,50 & 3,00 & 0,50 & 3,00 & 0,50 & 3,00 & & - & & - \\
\hline Ovos & $\mathrm{Dz}$ & 3,00 & 1,00 & 3,00 & 3,00 & 9,00 & 3,00 & 9,00 & & - & & - \\
\hline Leite & $\mathrm{L}$ & 1,79 & 0,80 & 1,43 & 0,25 & 0,45 & 0,25 & 0,45 & & - & 0,50 & 0,90 \\
\hline Sal & $\mathrm{Kg}$ & 0,93 & & & & & & & 0,09 & 0,08 & 0,09 & 0,08 \\
\hline Gordura & $\mathrm{L}$ & 2,90 & & & & & & & 0,20 & 0,58 & 0,75 & 2,18 \\
\hline Água & $\mathrm{L}$ & 0,45 & & & & & & & 3,00 & 1,35 & 1,00 & 0,45 \\
\hline Sal amoníaco & $\mathrm{Kg}$ & 3,80 & 0,09 & 0,32 & 0,09 & 0,32 & 0,09 & 0,32 & & - & & - \\
\hline Embalagem & un & 0,05 & 4,00 & 0,20 & 6,00 & 0,30 & 5,00 & 0,25 & 19,00 & 0,95 & 20,00 & 1,00 \\
\hline
\end{tabular}




\begin{tabular}{|c|c|c|c|c|c|c|c|c|c|c|c|c|}
\hline \multicolumn{4}{|c|}{ MÃO DE OBRA DIRETA } & \multirow{2}{*}{\begin{tabular}{|l}
9,97 \\
1,58
\end{tabular}} & \multirow{2}{*}{$\mid \frac{}{1,00}$} & \multirow{2}{*}{\begin{tabular}{|l|}
31,55 \\
6,31
\end{tabular}} & \multirow{2}{*}{$\mid \frac{}{1,00}$} & \multirow{2}{*}{\begin{tabular}{|l|}
15,78 \\
6,31
\end{tabular}} & \multirow{2}{*}{\begin{tabular}{|l} 
\\
0,50
\end{tabular}} & \multirow{2}{*}{\begin{tabular}{|l}
7,89 \\
3,16
\end{tabular}} & \multirow{2}{*}{\begin{tabular}{|l} 
\\
0,30
\end{tabular}} & \multirow{2}{*}{\begin{tabular}{|l}
$\mathbf{1 2 , 9 4}$ \\
1,89
\end{tabular}} \\
\hline Amassar & $\mathrm{H}$ & 6,31 & 0,25 & & & & & & & & & \\
\hline Modelar & $\mathrm{H}$ & 6,31 & 0,50 & 3,16 & 1,00 & 6,31 & 0,50 & 3,16 & 0,50 & 3,16 & 1,50 & 9,47 \\
\hline Assar & $\mathrm{H}$ & 6,31 & 0,50 & 3,16 & 1,50 & 9,47 & 0,50 & 3,16 & & - & & - \\
\hline Caramelar & $\mathrm{H}$ & 6,31 & & & 1,00 & 6,31 & & - & & - & & - \\
\hline Embalar & $\mathrm{H}$ & 6,31 & 0,33 & 2,08 & 0,50 & 3,16 & 0,50 & 3,16 & 0,25 & 1,58 & 0,25 & 1,58 \\
\hline \multicolumn{4}{|c|}{ CUSTOS INDIRETOS } & 2,72 & & 3,52 & & 2,42 & & 1,55 & & 2,26 \\
\hline \multicolumn{4}{|l|}{ Depreciação } & 0,87 & & 1,16 & & 1,21 & & 0,45 & & 1,20 \\
\hline Balança & $\mathrm{H}$ & 0,33 & 0,25 & 0,08 & 0,25 & 0,08 & 0,25 & 0,08 & 0,25 & 0,08 & 0,25 & 0,08 \\
\hline Batedeira & $\mathrm{H}$ & 0,63 & 0,08 & 0,05 & 0,25 & 0,16 & 0,25 & 0,16 & & - & & - \\
\hline Forno Elétrico & $\mathrm{H}$ & 0,62 & 1,00 & 0,62 & 1,00 & 0,62 & 0,60 & 0,37 & 0,60 & 0,37 & 0,50 & 0,31 \\
\hline Sovadeira 1 & $\mathrm{H}$ & 0,58 & - & - & - & - & 0,50 & 0,29 & & - & 1,00 & 0,58 \\
\hline Sovadeira 2 & $\mathrm{H}$ & 0,46 & 0,25 & 0,12 & 0,66 & 0,30 & 0,66 & 0,30 & & - & 0,50 & 0,23 \\
\hline \multicolumn{4}{|c|}{ Energia Elétrica } & 1,85 & & 2,36 & & 1,21 & & 1,10 & & 1,06 \\
\hline Batedeira & $\mathrm{H}$ & 0,06 & 0,08 & 0,00 & 0,25 & 0,02 & 0,25 & 0,02 & & - & & - \\
\hline Forno Elétrico & $\mathrm{H}$ & 1,83 & 1,00 & 1,83 & 1,00 & 1,83 & 0,60 & 1,10 & 0,60 & 1,10 & 0,50 & 0,92 \\
\hline Sovadeira 1 & $\mathrm{H}$ & 0,11 & - & - & & - & 0,50 & 0,06 & & - & 1,00 & 0,11 \\
\hline Sovadeira 2 & $\mathrm{H}$ & 0,07 & 0,25 & 0,02 & 0,66 & 0,05 & 0,66 & 0,05 & & - & 0,50 & 0,04 \\
\hline Gás & $\mathrm{H}$ & 0,31 & & & 1,50 & 0,47 & & - & & - & & - \\
\hline \multicolumn{4}{|c|}{ TOTAL DO CUSTO DE PRODUÇÃO } & 33,33 & & 68,58 & & 45,86 & & 20,10 & & 26,85 \\
\hline \multicolumn{4}{|c|}{ TOTAL POR LOTE - KG } & 8,35 & & 11,875 & & 9,64 & & 19,00 & & 20,00 \\
\hline \multicolumn{4}{|c|}{ CUSTO POR KG } & 3,99 & & 5,78 & & 4,76 & & 1,06 & & 1,34 \\
\hline
\end{tabular}

Fonte: Produção dos autores

Na tabela 7 estão evidenciados os custos de produção dos cinco produtos, agrupados por tipo. Em relação ao produto biscoito rosca de milho é possível observar que o custo com materiais diretos representa $62 \%$, enquanto o custo de mão de obra direta representa 30\% e os custos indiretos $8 \%$. Isso evidencia que o processo de produção representa um pouco mais de 1/3 do total de produção. Essa baixa participação dos custos de transformação, em parte é explicada, pelo fato do empreendimento ter um volume muito pequeno de custos indiretos. Para isso se deve ao fato do mesmo não ter custos de aluguel e por ser informal, e também não apresentar gastos com as obrigações legais. 
Em relação ao produto biscoito caramelado, observa-se que o custo de produção desse biscoito é de $\mathrm{R} \$ 5,78$ ao $\mathrm{kg}$. Pelo fato do produto ter o processo de modelar e caramelar todo manual, sem o auxílio de máquina, fica evidenciada a maior necessidade de MOD, sendo representada por $46,03 \%$ do custo do produto.

O custo de produção biscoito colonial desse biscoito é de R \$ 4,76 ao kg. Esse biscoito possui grande concentração de custo com materiais, onde apresenta $60,32 \%$ do total do custo do produto. Pelo fato deste produto ter o processo de modelar com o auxílio de máquina, além de tornar o processo produtivo mais rápido, também é utilizada uma menor quantidade de horas de MOD, tendo representatividade de $34,40 \%$ sobre o total do custo do produto.

Em relação ao custo de produção do pão de milho se pode observar que o seu custo de produção é de R\$ 1,06 por unidade. Este pão possui um processo produtivo rápido, onde a MOD tem representatividade de $39,27 \%$, pelo fato de grande parte do processo ser feito manualmente, o mesmo quase não possui custo indireto, pois utiliza somente um equipamento, assim os custos indiretos correspondem a 7,72\%. Este item possui maior concentração no custo com materiais diretos, tendo equivalência de 53,01\% do total do custo do produto. O produto pão de trigo apresenta como custo R \$1,34 por unidade. Este produto tem um processo produtivo demorado, onde o processo modelar mesmo com auxílio de máquina é demorado, assim necessitando de mais de uma hora de MOD. Devido a este procedimento detalhado, o custo com MOD corresponde $48,18 \%$, percentual maior que material direto, representado por 43,37\%. Já os custos indiretos identificou-se um montante de $8,45 \%$ sobre o custo total do produto.

A tabela 8, evidencia, de forma, sintética, o custo de produção final dos cinco produtos fabricado pela Pão e Biscoito, podendo-se visualizar a quantidade média produzida por mês, o custo unitário e o custo total mensal.

Tabela 8: Resumo do custo por mês

\begin{tabular}{|c|c|c|c|c|}
\hline Nome do produto & Und & $\begin{array}{l}\text { Quantidade } \\
\text { produzida }\end{array}$ & $\begin{array}{l}\text { Custo } \\
\text { unitário }\end{array}$ & $\begin{array}{l}\text { Custo total de } \\
\text { produção por } \\
\text { produto }\end{array}$ \\
\hline Rosca de Milho & KG & 100,20 & 3,99 & 399,97 \\
\hline $\begin{array}{l}\text { Biscoito } \\
\text { Caramelado }\end{array}$ & KG & 95,00 & 5,78 & 548,69 \\
\hline Biscoito Colonial & KG & 115,68 & 4,76 & 550,45 \\
\hline Pão de Milho & UND & 76 & 1,06 & 80,37 \\
\hline Pão de Trigo & UND & 80 & 1,34 & 107,44 \\
\hline
\end{tabular}

Fonte: Produção dos autores 
Em uma análise geral pode-se observar que, os dois tipos de pães além de possuírem custos unitários bem menores que os demais itens (biscoitos), o volume de produção de ambos também é inferior. Já os biscoitos caramelado e colonial apresentam os custos unitários mais elevados entre os cinco produtos. Já a rosca de milho possui um custo unitário intermediário e uma alta produção.

\subsubsection{Margem de contribuição e lucro atual}

A margem de contribuição pode ser evidenciada unitária e total. A mesma é considerada uma das principais ferramentas nas decisões relacionadas a grandes vendas, por exemplo, com o cálculo da margem de contribuição total é possível fazer uma análise de redução de preço e verificar qual seria o ganho na quantidade. Ou também permite discutir quanto à produção de determinado produto, ou seja, se tal item deve ou não continuar sendo comercializado. Esses são alguns exemplos de quanto é importante o cálculo da margem de contribuição em uma empresa.
Em razão do empreendimento estudado ser informal e suas atividades serem exercidas pela proprietária, foi identificada apenas uma despesa variável, que corresponde ao custo de entrega dos produtos (quando necessário), porém ao ser diluída essa despesa nos itens estudados, identificou-se um baixo percentual (inferior a um), que ao ser levado em consideração no cálculo, não apresentaria mudanças significativas no valor final. Além disso, a maioria da produção não tem esse custo de entrada, diante disso, entendeu-se que esta despesa variável não seria considerada no cálculo da margem de contribuição e lucro. Mesmo assim, nos demonstrativos, entende-se que seria interessante evidenciar a necessidade de se considerar a despesa variável para determinar a margem e o lucro, visto que, em muitas situações ela pode ser muito significativa.

De acordo com os custos de cada produto apontados, anteriormente, identificou-se os seguintes custos como sendo variáveis: matéria-prima, mão de obra direta e energia elétrica.

Tabela 9: Cálculo da margem de contribuição - unitária e total

\begin{tabular}{l|l|l|l|l|l|l}
\hline Produto & $\begin{array}{l}\text { Preço } \\
\text { venda }\end{array}$ & $\begin{array}{l}\text { Custo } \\
\text { variável } \\
\text { unitário }\end{array}$ & $\begin{array}{l}\text { Despesa } \\
\text { variável } \\
\text { unitária }\end{array}$ & $\begin{array}{l}\text { Margem de } \\
\text { Contribuiçãá } \\
\text { o unitária }\end{array}$ & $\begin{array}{l}\text { Quant. } \\
\text { Produ } \\
\text { zida }\end{array}$ & $\begin{array}{l}\text { Margem de } \\
\text { Contribuiç } \\
\text { ão total }\end{array}$ \\
\hline $\begin{array}{l}\text { Rosca de } \\
\text { Milho }\end{array}$ & 7,50 & 3,89 & 0,00 & 3,61 & 100,20 & 361,94 \\
$\begin{array}{l}\text { Biscoito } \\
\text { Caramelado }\end{array}$ & 8,00 & 5,68 & 0,00 & 2,32 & 95,00 & 220,61 \\
$\begin{array}{l}\text { Biscoito } \\
\text { Colonial }\end{array}$ & 7,50 & 4,63 & 0,00 & 2,87 & 115,68 & 331,62 \\
$\begin{array}{l}\text { Pão de Milho } \\
2,00\end{array}$ & 1,03 & 0,00 & 0,97 & 76 & 73,45 \\
Pão de Trigo & 2,00 & 1,28 & 0,00 & 0,72 & 80 & 57,38 \\
\hline \begin{tabular}{l} 
Total - Margem de Contribuição Total \\
\hline
\end{tabular}
\end{tabular}

Fonte: Produção dos autores 
Na tabela 9 pode-se observar que na linha de biscoitos, o produto rosca de milho é o que mais contribui, apresentando uma margem de contribuição unitária de $\mathrm{R}$ \$3,61 e margem de contribuição total de $\mathrm{R} \$ 361,94$. Em segundo lugar fica o biscoito colonial com uma margem de contribuição unitária de $\mathrm{R} \$$ 2,87 e em terceiro lugar, o biscoito caramelado com a menor margem de contribuição unitária de R \$2,32 e total de R\$220,61. Na linha de pães observa-se que o pão de milho possui uma margem de contribuição unitária de $\mathrm{R} \$ 0,97$, mesmo tendo uma produção menor, o mesmo também se mantém com uma margem de contribuição total superior ao pão de trigo, que possui uma margem de contribuição unitária de apenas $\mathrm{R}$ \$,72.

Além de determinar a margem (informação muito importante para o gerenciamento de qualquer negócio) entende-se ser importante também determinar o valor do lucro unitário de cada produto e o lucro total do empreendimento. Uma vez que já foi determinada a margem de contribuição, para encontrar o lucro, basta deduzir da margem (diferença entre o preço de venda, a soma dos custos e despesas vaiáveis) o valor dos custos fixos e das despesas fixas. Em relação aos custos fixos, foram considerados o custos indiretos relacionados a depreciação, já que foi o único tipo de custo fixo que foi identificado. Já em relação ao fato do empreendimento atuar na informalidade, além de não apresentar despesa variável, o mesmo também não apresentou despesa fixa, pois a entidade não possui custo de escritório (que poderia ser uma despesa fixa se ele atuasse na formalidade), aluguel (se operasse em imóvel alugado), entre outras despesas que são classificadas como fixas.

A tabela 10 apresenta os valores que compõem o cálculo para a determinação do lucro unitário e total de cada produto, bem como, o lucro total do empreendimento. Lembrando que, nesse cálculo só foi considerado como custo fixo o valor da depreciação das máquinas e que em função do que já foi mencionado anteriormente, não está sendo considerado nenhum valor para fins de despesa fixa e nem de despesa variável.

Tabela 10: Cálculo do Lucro

\begin{tabular}{|c|c|c|c|c|c|c|c|c|}
\hline \multirow{2}{*}{ Produto } & \multirow{2}{*}{$\begin{array}{l}\text { Preço } \\
\text { venda }\end{array}$} & \multirow{2}{*}{$\begin{array}{l}\text { Custo } \\
\text { variável } \\
\text { unitário }\end{array}$} & \multirow{2}{*}{$\begin{array}{l}\text { Custo } \\
\text { fixo } \\
\text { unitário }\end{array}$} & \multirow{2}{*}{$\begin{array}{l}\text { Desp. } \\
\text { variável } \\
\text { unitária }\end{array}$} & \multirow{2}{*}{$\begin{array}{l}\text { Desp. } \\
\text { fixa } \\
\text { unitária }\end{array}$} & \multirow{2}{*}{$\begin{array}{l}\text { Quant. } \\
\text { Produ } \\
\text { zida }\end{array}$} & \multicolumn{2}{|l|}{ Lucro } \\
\hline & & & & & & & Unitário & Total \\
\hline $\begin{array}{l}\text { Rosca de } \\
\text { Milho }\end{array}$ & 7,50 & 3,89 & 0,10 & 0,00 & 0,00 & 100,20 & 3,51 & 1,53 \\
\hline $\begin{array}{l}\text { Biscoito } \\
\text { Caramelado }\end{array}$ & 8,00 & 5,68 & 0,10 & 0,00 & 0,00 & 95,00 & 2,22 & 1,31 \\
\hline $\begin{array}{l}\text { Biscoito } \\
\text { Colonial }\end{array}$ & 7,50 & 4,63 & 0,13 & 0,00 & 0,00 & 115,68 & 2,74 & 7,15 \\
\hline Pão de Milho & 2,00 & 1,03 & 0,02 & 0,00 & 0,00 & 76,00 & 0,94 & 63 \\
\hline Pão de Trigo & 2,00 & 1,28 & 0,06 & 0,00 & 0,00 & 80,00 & 0,66 & 56 \\
\hline Lucro Total & & & & & & & & 004,18 \\
\hline
\end{tabular}

Fonte: Produção dos autores 
Na tabela 10, observa-se que o produto rosca de milho além de apresentar a melhor margem de contribuição também gera melhor lucro, mesma situação acontece com os demais biscoitos, onde o biscoito colonial mantém-se em segundo e o biscoito caramelado em terceiro lugar. Nos pães, o pão de milho mostra uma lucratividade de $47 \%$ sobre o preço de venda. Já o pão de trigo pelo fato de apresentar um custo fixo maior, seu lucro cai para $33 \%$.

Conforme comentado anteriormente, a proprietária não possui pró-labore, pois os resultados obtidos são revertidos para si. Com um lucro de $\mathrm{R} \$ 1.004,18$, pode-se afirmar que a dona da Pão e Biscoito, possui um bom retorno, considerando-se que a produção atual ocorre em turno parcial.

\subsection{Rentabilidade atual}

Após realizado o levantamento dos custos dos produtos, margem de contribuição e lucro, é possível identificar o retorno que cada produto proporciona ao estabelecimento estudado. Existem várias formas de se avaliar a rentabilidade de um produto. Ela pode ser determinada comparando-se o valor da margem de contribuição em relação ao preço de venda ou ao seu custo (podendo ser só em relação ao variável ou ao total), também pode ser determinada considerando-se o valor gerado de lucro, ao invés da margem.

Cada fórmula tem um objetivo diferente. A rentabilidade da margem em relação ao preço de venda permite saber o quanto cada produto contribui, na geração da margem total, em relação ao valor cobrado, ou seja, quanto do valor cobrado sobra para a empresa pagar seus custos e despesas fixas e gerar o lucro. A rentabilidade da margem de contribuição em relação ao custo variável, informa o quanto o produto está conseguindo gerar de margem em relação ao que é investido diretamente nele (custo). Isso permite ter uma percepção de qual é o retorno (em termos de margem) que cada produto está gerando a cada real que é investido diretamente nele, sempre considerando que o valor gerado de margem, não é lucro, já que, antes de chegar ao lucro, ainda é necessário cobrir os custos e despesas fixas. Já quando o lucro é a referência, a rentabilidade obtida representa o quanto o produto está gerando de lucro (em relação ao seu preço de venda ou ao seu custo), sendo que, nesse caso, diferente de quando é utilizada a margem, a rentabilidade obtida já representa o lucro líquido após todos os custos e despesas (sejam eles fixos ou variáveis).

Para fins do estudo, entende-se ser interessante evidenciar as quatro formas de se determinar a rentabilidade dos produtos, sendo que, para fins da determinação da rentabilidade (tanto da margem como lucro) em relação ao custo, optou-se por utilizar o custo variável. Essa escolha tem por base o fato que na prática, esse é o único investimento certo que o empreendimento tem que fazer para produzir os produtos, já que, os custos fixos incorporados aos produtos (via rateio) eles vão existir independentemente da produção do produto "A" ou "B".

Na tabela 11 estão evidenciadas as rentabilidades que os produtos estão gerando em relação ao preço de venda, tomando-se por base a margem de contribuição unitária gerada por cada produto.

Conforme tabela 11, pode-se observar que os produtos que apresentam maior rentabilidade são: rosca de milho e pão de milho, ambos geram um retorno de $48 \%$. Em uma análise geral, o produto que fornece menor rentabilidade sobre o preço de venda é o biscoito caramelado com um percentual de $29,03 \%$.

Na tabela 12 está evidenciada a rentabilidade dos produtos, gerada pela margem de contribuição unitária sobre o custo variável unitário. 
Tabela 11: Rentabilidade sobre o preço de venda

\begin{tabular}{l|l|l|l}
\hline Produto & $\begin{array}{l}\text { Preço de } \\
\text { venda }\end{array}$ & $\begin{array}{l}\text { Margem de } \\
\text { Contribuição } \\
\text { unitária }\end{array}$ & Rentabilidade \\
\hline Rosca de Milho & 7,50 & 3,61 & $48,16 \%$ \\
Biscoito Caramelado & 8,00 & 2,32 & $29,03 \%$ \\
Biscoito Colonial & 7,50 & 2,87 & $38,22 \%$ \\
Pão de Milho & 2,00 & 0,97 & $48,32 \%$ \\
Pão de Trigo & 2,00 & 0,72 & $35,86 \%$ \\
\hline
\end{tabular}

Fonte: Produção dos autores

Tabela 12: Rentabilidade sobre custo variável unitário

\begin{tabular}{lccc}
\hline Produto & $\begin{array}{l}\text { Custo Variável } \\
\text { unitário }\end{array}$ & $\begin{array}{l}\text { Margem de } \\
\text { Contribuição } \\
\text { unitária }\end{array}$ & Rentabilidade \\
\hline Rosca de Milho & 3,89 & 3,61 & $92,91 \%$ \\
Biscoito Caramelado & 5,68 & 2,32 & $40,90 \%$ \\
Biscoito Colonial & 4,63 & 2,87 & $61,87 \%$ \\
Pão de Milho & 1,03 & 0,97 & $93,50 \%$ \\
Pão de Trigo & 1,28 & 0,72 & $55,91 \%$ \\
\hline
\end{tabular}

Fonte: Produção dos autores

No cálculo desta rentabilidade nota-se que no grupo dos biscoitos o item rosca de milho mantém-se em destaque com uma rentabilidade de $92,91 \%$, enquanto que o biscoito colonial possui um retorno de $61,87 \%$. Por último fica o biscoito caramelado com a menor rentabilidade tanto na linha de biscoitos, quanto em uma análise geral de todos os produtos, apresentando um retorno de 40,90\%. Já na categoria pães o pão de milho permanece na liderança da melhor rentabilidade, apresentando $93,50 \%$ de retorno, destaca-se também como produto com maior rentabi- lidade dentre os produtos avaliados. No item pão de trigo o retorno cai para 55,91\%.

Após evidenciar e avaliar a rentabilidade que cada produto gera, considerando-se a margem de contribuição em relação ao preço de venda e o custo variável unitário, a seguir serão evidenciadas as mesmas rentabilidades, agora considerando o lucro unitário.

Na tabela 13 está sendo mostrada a rentabilidade sobre o lucro, pode-se verificar que o produto pão de milho mostra-se $o$ mais rentável, apresentando um retorno de $47,12 \%$, já o pão de trigo apresenta uma ren- 
tabilidade de 32,85\%. Nos biscoitos, a rosca de milho permanece como a mais rentável, com um percentual de 46,78. Após é seguin- do pelo biscoito colonial, com rentabilidade de $36,55 \%$ e por último fica o biscoito caramelado com retorno de $27,80 \%$.

Tabela 13: Rentabilidade sobre o lucro

\begin{tabular}{lrrr}
\hline Produto & \multicolumn{1}{|l|}{$\begin{array}{l}\text { Preço de } \\
\text { venda }\end{array}$} & Lucro & Rentabilidade \\
\hline Rosca de Milho & 7,50 & 3,51 & $46,78 \%$ \\
$\begin{array}{l}\text { Biscoito } \\
\text { Caramelado }\end{array}$ & 8,00 & 2,22 & $27,80 \%$ \\
$\begin{array}{l}\text { Biscoito } \\
\text { Colonial }\end{array}$ & 7,50 & 2,74 & $36,55 \%$ \\
Pão de Milho & 2,00 & 0,94 & $47,12 \%$ \\
Pão de Trigo & 2,00 & 0,66 & $32,85 \%$ \\
\hline
\end{tabular}

Fonte: Produção dos autores

\subsection{Estudo de viabilidade do empreendi- mento se tornar formal}

Com a análise da atual rentabilidade, é possível a Pão e Biscoito examinar a viabilidade ou não de tornar-se uma empresa formal. Atualmente, no Brasil existem quatro formas de tributação que uma empresa pode optar, dependendo das condições estabelecidas pelo fisco para cada uma delas e/ou em função das vantagens que cada uma pode representar para a empresa (Empreendedor Individual; Simples Nacional; Lucro Presumido; Lucro real).

Em relação à Pão e Biscoitos, por ser um empreendimento muito pequeno e possuir apenas um funcionário, entende-se, ser necessário apenas avaliar as duas primeiras opções: Empreendedor Individual e Simples Nacional.

\subsubsection{Empreendedor Individual}

Conforme legislação prevê, um empreendimento ao sair da informalidade e ter enquadramento como Empreendedor Indi- vidual - EI precisa ter um faturamento anual de no máximo $\mathrm{R} \$ 60.000,00$, acima deste valor passa automaticamente para o Simples Nacional. Além do limite de receita bruta anual, este enquadramento possui mais algumas regras. Em relação à mão de obra, o EI somente pode ter um funcionário, sendo que, além dos custos trabalhistas, como qualquer empresa, também terá que recolher $11 \%$ para a previdência sobre o valor salário do empregado, sendo que, $3 \%$ se referem aos custos que o EI tem, já os outros $8 \%$ é de responsabilidade do empregado e devem ser pagos por este. No caso da Pão e Biscoito, o custo com a previdência será representado por $\mathrm{R} \$ 15,00$ (R\$ 500,00 x 3\%).

Além do custo previdenciário, existem outros gastos que o EI possui. Embora ele não esteja obrigado a pagar um tributo sobre o faturamento (despesa variável) ou sobre o lucro, ele é obrigado a pagar um valor mensal (valor fixo, independente do faturamento), enquanto o limite de faturamento permitir ele enquadrado como EI. A Pão e Bis- 
coito, por ser uma indústria, o seu imposto único é formado pelos seguintes valores: R\$ 1,00 (ICMS) para o estado, mais R \$ 31,10 referente ao INSS (reduzido a 5\% do salário mínimo), quanto aos impostos do Governo Federal o valor é zero.

Tabela 14: Cálculo do Lucro considerando o enquadramento como EI

\begin{tabular}{|c|c|c|c|c|c|c|c|c|}
\hline \multirow{2}{*}{ Produto } & \multirow{2}{*}{$\begin{array}{l}\text { Preço } \\
\text { venda }\end{array}$} & \multirow{2}{*}{$\begin{array}{l}\text { Custo } \\
\text { variável } \\
\text { unitário }\end{array}$} & \multirow{2}{*}{$\begin{array}{l}\text { Custo } \\
\text { fixo } \\
\text { unitário }\end{array}$} & \multirow{2}{*}{$\begin{array}{l}\text { Despesa } \\
\text { variável } \\
\text { unitária }\end{array}$} & \multirow{2}{*}{$\begin{array}{l}\text { Despesa } \\
\text { fixa } \\
\text { unitária }\end{array}$} & \multirow{2}{*}{$\begin{array}{l}\text { Quant. } \\
\text { Produzida }\end{array}$} & \multicolumn{2}{|l|}{ Lucro } \\
\hline & & & & & & & $\begin{array}{l}\text { Unitá } \\
\text { rio }\end{array}$ & Total \\
\hline \multicolumn{9}{|l|}{ Rosca de } \\
\hline Milho & 7,50 & 3,89 & 0,10 & 0,00 & 0,00 & 100,20 & 3,51 & 351,53 \\
\hline \multicolumn{9}{|l|}{ Biscoito } \\
\hline Caramelado & 8,00 & 5,68 & 0,10 & 0,00 & 0,00 & 95,00 & 2,22 & 211,31 \\
\hline \multicolumn{9}{|l|}{ Biscoito } \\
\hline Colonial & 7,50 & 4,63 & 0,13 & 0,00 & 0,00 & 115,68 & 2,74 & 317,15 \\
\hline Pão de Milho & 2,00 & 1,03 & 0,02 & 0,00 & 0,00 & 76 & 0,94 & 71,63 \\
\hline Pão de Trigo & 2,00 & 1,28 & 0,06 & 0,00 & 0,00 & 80 & 0,66 & 52,56 \\
\hline Lucro Total & & & & & & & & $1.004,18$ \\
\hline Despesas Fixas & & & & & & & & 127,10 \\
\hline Lucro Líquido & & & & & & & & 877,08 \\
\hline
\end{tabular}

Fonte: Produção dos autores

A tabela 14 está evidenciado o lucro líquido da Pão e Biscoito ao optar pelo EI. Na despesa fixa está sendo levado em consideração o imposto único de $\mathrm{R} \$ 32,10$, o encargo previdenciário de $\mathrm{R} \$ 15,00$. Além destas duas despesas fixas também está sendo considerada a despesa de $\mathrm{R} \$ 80,00$ com escritório de contabilidade, por mais que a legislação não exija a contabilidade formal do EI, é importante que a Pão e Biscoito possua um controle das suas movimentações (receitas e despesas), bem como ter uma assessoria para saber quais são os procedimentos relacionados ao funcionário (folha de pagamento, férias, $13^{\circ}$ salário, entre outros) e a própria gestão do negócio.
Como se pode observar pelas informações da tabela 18, o lucro que antes da opção pelo EI era de R $\$ 1.004,18$, ao optar pelo EI, passou para $\mathrm{R} \$ 877,08$, representando uma redução de $\mathrm{R} \$ 127,10$, que corresponde a $14,43 \%$. Embora a redução em percentual seja significativa, nesse momento, ela pode representar uma grande oportunidade para aumentar o faturamento, já que uma vez que o empreendimento passar para formalidade, o seu mercado será maior (poderá passar a vender produtos para empresas que exigem nota fiscal) e com isso ter um aumento do seu lucro via aumento de faturamento. Para obter esse aumento, será necessário aumentar a margem de contribuição total em $\mathrm{R} \$ 127,10$ 
passando dos atuais $\mathrm{R} \$ 1.045,00$ (tabela 13) para $\mathrm{R} \$ 1.172,10$ (de forma a compensar esse aumento nas despesas fixas provocadas pela opção do EI), correspondendo um aumento de $12,16 \%$. Para conseguir esse aumento na margem de contribuição total, será necessário aumentar também o faturamento em $12,16 \%$. Isso quer dizer que o faturamento atual que é de R\$2.691,10 (preço de venda atual multiplicado pela quantidade produzida) deveria passar para $\mathrm{R} \$ 3.018,34$. Acredita-se que em função dos benefícios que a formalização trás, principalmente, a segurança do negócio (por estar na legalidade) e a oportunidade de aumentar as vendas (atendendo novos mercados que exigem documentação), a Pão e Biscoito deveria considerar essa alternativa como uma boa opção.

No entanto, é importante considerar que se o faturamento crescer em mais de $86 \%$, ele vai ultrapassar os $\mathrm{R} \$ 5.000,00$ (limite máximo mensal para permanecer como EI), a partir daí, a Pão e Biscoito passará a ser enquadrada diretamente no Simples Nacional. Diante disso, entende-se também ser necessário avaliar essa opção.

\subsubsection{Simples Nacional}

De acordo com a legislação, uma empresa que tem o enquadramento do Simples Nacional, ao efetuar a compra de matéria-prima, a mesma não possui nenhum tipo de crédito de imposto. Assim, na atual estrutura de custos, os itens que compõem a matéria- prima não seriam afetados se a empresa passasse a ser formal, ou seja, os custos de seus produtos não seriam afetados. Outro fator que também não impactaria no custo total seria a mão de obra direta, uma vez que, já foram considerados todos os encargos trabalhistas, sendo que, por ser optante do Simples
Nacional, a Pão e Biscoito não teria nenhum encargo previdenciário (além do recolhido via Simples). Também em relação aos custos indiretos, entende-se que não haveria alterações significativas no custo unitário dos produtos. As mudanças mais significativas ocorreriam nas despesas variáveis (pagamento do Simples, com base no percentual devido, sobre o preço de venda) e nas despesas fixas (custo com escritório de contabilidade, taxas e etc.).

Sendo assim, ao mudar da informalidade para uma empresa tributada pelo Simples Nacional, a Pão e Biscoito precisa analisar todas as alterações que a formalidade irá causar. Dentre várias mudanças no seu resultado, destaca-se a despesa variável - imposto Simples Nacional (conforme receita bruta). De acordo com a tabela (anexo A) do Simples Nacional para indústrias, a Pão e Biscoito passaria a ter uma despesa variável de 4,50\%.

Além da despesa variável, a entidade também precisa incluir na sua lista de despesa fixa, a despesa com escritório de contabilidade, pois com a formalidade é necessário efetuar a prestação de contas ao governo. Conforme pesquisa, essa despesa fixa seria de $\mathrm{R} \$ 300,00$.

Na tabela 15 está evidenciado o cálculo da margem de contribuição (unitária e total) considerando-se a hipótese da Pão e Biscoito passar a ser tributada pelo Simples Nacional. O percentual utilizado para fins de tributação é de 4,50\%, percentual esse estabelecido pela legislação, para empresas que faturam até R\$ 180.000,00 anuais (Anexo A).

Como se pode perceber (tabela 15) a diferença da margem de contribuição gerada nas duas situações (informal e formal) é a despesa variável, que na hipótese da informalidade não existe e quando é considerada a hipótese da formalidade, em função da existência do tributo, exigido pelo Simples, passa a existir. 
Tabela 15: Cálculo da margem de contribuição - unitária e total - Simples Nacional

\begin{tabular}{l|c|c|c|c|c|c}
\hline \multicolumn{1}{c|}{ Produto } & Preço & $\begin{array}{c}\text { Custo } \\
\text { variável } \\
\text { unitário }\end{array}$ & $\begin{array}{c}\text { Despesa } \\
\text { variável } \\
\text { unitária }\end{array}$ & $\begin{array}{c}\text { Margem de } \\
\text { Contribuição } \\
\text { unitária }\end{array}$ & $\begin{array}{c}\text { Quantidade } \\
\text { Produzida }\end{array}$ & $\begin{array}{c}\text { Margem de } \\
\text { Contribuição } \\
\text { total }\end{array}$ \\
\hline Rosca de Milho & 7,50 & 3,89 & 0,34 & 3,27 & 100,20 & 328,12 \\
Biscoito Caramelado & 8,00 & 5,68 & 0,36 & 1,96 & 95,00 & 186,41 \\
Biscoito Colonial & 7,50 & 4,63 & 0,34 & 2,53 & 115,68 & 292,58 \\
Pão de Milho & 2,00 & 1,03 & 0,09 & 0,88 & 76,00 & 66,61 \\
Pão de Trigo & 2,00 & 1,28 & 0,09 & 0,63 & 80,00 & 50,18 \\
\hline
\end{tabular}

Fonte: Produção dos autores

De acordo com os dados apresentados na tabela 15 , pode-se observar que com a despesa variável - imposto, os produtos apresentam redução nas suas margens de contribuição unitária e total. Em uma análise geral nota-se que, ao passar para a formalidade, a Pão e Biscoito, terá uma redução de 11,59\% na sua margem de contribuição total, onde antes apresentava um total de $\mathrm{R} \$ 1.045,00$ e com a formalidade sua margem de contribuição total passou a ser $\mathrm{R} \$ 923,90$. A redução em reais será de $\mathrm{R} \$ 121,10$ e corresponde exatamente ao valor a ser recolhido de tributo.

No entanto, como já informado, ao passar a ser um empreendimento formal, não é só o valor do tributo que vai impactar na geração do resultado final. Outras despesas surgem em função da formalidade. Para avaliar o impacto total, é necessário determinar a diferença entre o lucro antes e depois da formalidade.

Seguindo o mesmo critério utilizado para determinar o lucro na situação informal, a seguir será evidenciado o cálculo do lucro, considerando-se a hipótese da Pão e Biscoito passar a ser um empreendimento atuando na formalidade. Para esse fim, além da adição do tributo (como despesa variável), considerou-se R \$300,00 como despesas fixas, correspondentes aos custos com o escritório de contabilidade (honorários, taxas etc.). Certamente, esse valor deveria ser melhor avaliado caso ocorra a decisão da proprietária em formalizar seu empreendimento, já que ele pode não representar a despesa fixa real que o empreendimento vai passar a ter.

Diferente do que ocorreu com a determinação da margem de contribuição, onde o tributo pago sobre o preço de venda (Simples) foi o único valor que impactou na determinação da margem, em função da opção pela formalidade, no caso do lucro existem dois itens que influenciam na determinação do lucro. Além do tributo (que é considerado tanto na determinação da margem como do lucro, por ser uma despesa variável), na determinação do lucro, também são consideradas as despesas fixas.

Com o objetivo de evidenciar os dois impactos, na determinação do lucro, em função dos dois tipos de despesas, serão apresentadas duas novas demonstrações do lucro 
gerado por produto. A primeira (tabela 16) considerando apenas a inclusão da despesa variável (tributo) e deduzido as despesas fixas pelo seu total (essa é uma forma mais simples e fácil de compreender, muito utilizada para fins gerencias).

Tabela 16: Cálculo do Lucro - Simples Nacional - sem as despesas fixas

\begin{tabular}{|c|c|c|c|c|c|c|c|c|}
\hline \multirow{2}{*}{ Produto } & \multirow{2}{*}{$\begin{array}{l}\text { Preço } \\
\text { de } \\
\text { venda }\end{array}$} & \multirow{2}{*}{$\begin{array}{l}\text { Custo } \\
\text { variável } \\
\text { unitário }\end{array}$} & \multirow{2}{*}{\begin{tabular}{|l|} 
Custo \\
fixo \\
unitário
\end{tabular}} & \multirow{2}{*}{$\begin{array}{l}\text { Despesa } \\
\text { variável } \\
\text { unitária }\end{array}$} & \multirow{2}{*}{$\begin{array}{l}\text { Despesa } \\
\text { fixa } \\
\text { unitária }\end{array}$} & \multirow{2}{*}{$\begin{array}{l}\text { Quantidade } \\
\text { produzida }\end{array}$} & \multicolumn{2}{|l|}{ Lucro } \\
\hline & & & & & & & Unitário & Total \\
\hline Rosca de Milho & 7,50 & 3,89 & 0,10 & 0,34 & 0,00 & 100,20 & 3,17 & 317,71 \\
\hline Biscoito Caramelado & 8,00 & 5,68 & 0,10 & 0,36 & 0,00 & 95,00 & 1,86 & 177,11 \\
\hline Biscoito Colonial & 7,50 & 4,63 & 0,13 & 0,34 & 0,00 & 115,68 & 2,40 & 278,11 \\
\hline Pão de Milho & 2,00 & 1,03 & 0,02 & 0,09 & 0,00 & 76,00 & 0,85 & 64,79 \\
\hline Pão de Trigo & 2,00 & 1,28 & 0,06 & 0,09 & 0,00 & 80,00 & 0,57 & 45,36 \\
\hline Lucro Bruto & & & & & & & & 883,08 \\
\hline Despesa Fixa & & & & & & & & 300,00 \\
\hline Lucro Líquido & & & & & & & & 583,08 \\
\hline
\end{tabular}

Fonte: Produção dos autores

A tabela 16 evidencia o lucro que a Pão e Biscoito teria, caso passasse a ser uma empresa tributada pelo Simples Nacional, considerando-se apenas o efeito de passar a pagar o referido tributo. Nota-se que o seu lucro cai de $\mathrm{R} \$ 1.004,18$ para $\mathrm{R} \$ 883,08$, obtendo uma redução de 12,06\%.

Com o resultado positivo de $\mathrm{R} \$ 883,08$ a empresa ainda assim possui um lucro aceitável, porém, além do tributo, ao optar pela formalização, também devem ser consideradas as despesas fixas que surgem em decorrência dessa opção. Para fins do estudo, foi considerado o valor de R\$300,00. Ao ser incluída esta despesa ( $\mathrm{R} \$ 300,00)$, nota-se que o lucro vai reduzir mais ainda, passando a ser de apenas $\mathrm{R} \$ 583,08$. Ou seja, considerando apenas o efeito tributário, a redução, no lucro, seria de $12,06 \%$, passando para $41,93 \%$, ao ser considerada também a despesa fixa. Isso in- dica que, nesse caso, a redução apresentada pelo surgimento da despesa fixa é bem maior que a provocada pela tributação, já que a redução do lucro provocada pelo tributo é de $\mathrm{R} \$ 121,10$ e a provocada pelo surgimento da despesa fixa (escritório) é de $\mathrm{R} \$ 300,00$, representando $248 \%$ maior.

$\mathrm{Na}$ tabela 17 está sendo mostrada outra forma de considerar a despesa fixa. Para fins de distribuição das despesas fixas aos diferentes produtos, utilizou-se o valor da margem de contribuição total como base de rateio, de forma a se obter o percentual que as despesas fixas representam em relação ao total do faturamento (tabela 17) e com base nesse percentual, se atribui ao valor unitário da despesa fixa para cada produto considerando a participação que ele representa em relação ao preço de venda de cada produto, respectivamente. 
Tabela 17: Distribuição da despesa fixa

\begin{tabular}{l|ll|l|l|l}
\hline \multirow{2}{*}{ Produto } & \multirow{4}{*}{ Quantidade } & \multicolumn{3}{l|}{$\begin{array}{l}\text { Margem de contribuição } \\
\text { total }\end{array}$} & \multicolumn{2}{l}{ Despesa Fixa } \\
\cline { 3 - 7 } & & Valor Total & $\%$ & Valor Total & Valor Unitário \\
\hline Rosca de Milho & 100,20 & 328,12 & $35,52 \%$ & 106,55 & 1,06 \\
Biscoito Caramelado & 95,00 & 186,41 & $20,18 \%$ & 60,53 & 0,64 \\
Biscoito Colonial & 115,68 & 292,58 & $31,67 \%$ & 95,00 & 0,82 \\
Pão de Milho & 76,00 & 66,61 & $7,21 \%$ & 21,63 & 0,28 \\
Pão de Trigo & 80,00 & 50,18 & $5,43 \%$ & 16,29 & 0,20 \\
\hline Total & $\mathbf{9 2 3 , 9 0}$ & $\mathbf{1 0 0 , 0 0 \%}$ & $\mathbf{3 0 0 , 0 0}$ & \\
\hline
\end{tabular}

Fonte: Produção dos autores

A tabela 18 mostra o lucro da Pão e Biscoito, de acordo com o rateio da despesa fixa, assim evidenciando uma despesa fixa unitária alocada aos produtos oferecidos.

Nota-se que ao alocar uma despesa fixa unitária, o lucro unitário dos produtos cai em média 34,25\%. Apesar de ser alocada de forma diferente a despesa fixa, o resultado final (lucro) não sofre alteração. No entanto, é importante considerar que se ocorrer qualquer variação no valor da despesa fixa ou principalmente no volume da produção, o lucro unitário muda. Para fins gerenciais, entende-se que a primeira forma é a mais simples e prática para se obter o resultado, pois além de não precisar fazer o rateio, a mesma possibilita de forma rápida mudar o valor das despesas fixas e definir qual será o novo faturamento para manter o lucro ou efeito no lucro com o mesmo faturamento.

Tabela 18: Cálculo do Lucro - Simples Nacional

\begin{tabular}{|c|c|c|c|c|c|c|c|c|}
\hline \multirow{2}{*}{ Produto } & \multirow{2}{*}{$\begin{array}{l}\text { Preço } \\
\text { de } \\
\text { venda }\end{array}$} & \multirow{2}{*}{$\begin{array}{l}\text { Custo } \\
\text { variável } \\
\text { unitário }\end{array}$} & \multirow{2}{*}{$\begin{array}{l}\text { Custo } \\
\text { fixo } \\
\text { unitário }\end{array}$} & \multirow{2}{*}{$\begin{array}{l}\text { Despesa } \\
\text { variável } \\
\text { unitária }\end{array}$} & \multirow{2}{*}{$\begin{array}{l}\text { Desp. } \\
\text { fixa } \\
\text { unitária }\end{array}$} & \multirow{2}{*}{$\begin{array}{l}\text { Quantidade } \\
\text { produzida }\end{array}$} & \multicolumn{2}{|l|}{ Lucro } \\
\hline & & & & & & & Unitário & Total \\
\hline Rosca de Milho & 7,50 & 3,89 & 0,10 & 0,34 & 1,06 & 100,20 & 2,11 & 211,17 \\
\hline Biscoito Caramelado & 8,00 & 5,68 & 0,10 & 0,36 & 0,64 & 95,00 & 1,23 & 116,58 \\
\hline Biscoito Colonial & 7,50 & 4,63 & 0,13 & 0,34 & 0,82 & 115,68 & 1,58 & 183,10 \\
\hline Pão de Milho & 2,00 & 1,03 & 0,02 & 0,09 & 0,28 & 76,00 & 0,57 & 43,16 \\
\hline Pão de Trigo & 2,00 & 1,28 & 0,06 & 0,09 & 0,20 & 80,00 & 0,36 & 29,06 \\
\hline Lucro Total & & & & & & & & 583,08 \\
\hline
\end{tabular}

Fonte: Produção dos autores 
A segunda só é necessária caso se deseje saber qual o real lucro unitário. Lembrando que o valor utilizado como despesa fixa poderá ser diferente ao optar pela formalidade.

Considerando o atual faturamento e o valor das despesas fixas geradas em função da formalidade ( $\mathrm{R} \$ 300,00)$, nota-se que a despesa fixa é praticamente 3 vezes maior que a despesa variável (imposto do Simples Nacional), porém, na medida que o faturamento aumenta, a despesa fixa não sofre alteração.

Essa análise indica que, ao optar pela formalização, é necessário considerar não só o efeito do tributo, mas sim todas as demais despesas que vão surgir em decorrência dessa opção. Também foi possível perceber que, dependendo do volume faturado, o custo tributário é menor que o custo das obrigações acessórias, já que o tributo é proporcional ao valor faturado, em contrapartida as despesas acessórias, praticamente todas são fixas.

Com a análise apresentada, observa-se que a Pão e Biscoito ao tornar-se uma empresa formal, via Simples Nacional, considerando-se a produção e venda atual, apresentaria uma redução muito significativa de seu lucro.
Para que a empreendimento tenha um lucro, após a opção, pelo Simples Nacional, seja igual ao obtido na informalidade ( $\mathrm{R} \$$ $1.004,18)$, é necessário que ela aumente sua produção e venda em 45,48\% (tabela 19). Ou seja, caso a empresa passe a ser tributada pelo Simples, ela terá que aumentar sua produção e venda em praticamente $50 \%$, para isso, foi considerado que, tanto os custos fixos como as despesas fixas não sofreriam aumento em função do crescimento do volume produzido/vendido. Para fins de exemplificação foi considerado que o aumento necessário de $45,58 \%$, na margem de contribuição total, seria obtido de forma proporcional em todos os produtos, o que significa que o aumento da produção/venda seria de forma linear. No entanto, se a produção não for linear, é importante considerar que o interessante seria que o aumento da produção ocorresse em percentual maior nos produtos que geram maior margem de contribuição unitária, de forma que o volume de margem de contribuição total seria maior do que se o aumento maior ocorresse nos produtos de menor margem de contribuição.

Tabela 19: Projeção de venda atuando formalmente para ter o lucro atual

\begin{tabular}{l|l|l|l|l|l}
\hline Forma de atividade & Informal & Formal & \multicolumn{2}{l}{} \\
\hline Produção/venda & Atual & $\begin{array}{l}\text { Atual } \\
\text { sem } \\
\text { desp.fixa }\end{array}$ & $\begin{array}{l}\text { Atual } \\
\text { com } \\
\text { desp.fixa }\end{array}$ & $\begin{array}{l}\text { Necessária } \\
\text { lucro }= \\
\text { informal }\end{array}$ & $\begin{array}{l}\text { Variação } \\
\text { s/ atual }\end{array}$ \\
\hline Margem total prod.-Rosca de Milho & 361,94 & 328,12 & 328,12 & 477,68 & $45,58 \%$ \\
Margem total prod.-Biscoito Caramelado & 220,61 & 186,41 & 186,41 & 271,38 & $45,58 \%$ \\
Margem total prod.-Biscoito Colonial & 331,62 & 292,58 & 292,58 & 425,94 & $45,58 \%$ \\
Margem total prod.-Pão de Milho & 73,45 & 66,61 & 66,61 & 96,97 & $45,58 \%$ \\
Margem total prod.-Pão de Trigo & 57,38 & 50,18 & 50,18 & 73,04 & $45,58 \%$ \\
Total margem de todos os produtos & $1.045,00$ & 923,90 & 923,90 & $1.345,01$ & $45,58 \%$ \\
Total dos custos fixos (depreciação) & 40,82 & 40,82 & 40,82 & 40,82 & $0,00 \%$ \\
Total das despesas fixas (escritório) & 0,00 & 0,00 & 300,00 & 300,00 & $0,00 \%$ \\
\hline
\end{tabular}

Fonte: Produção dos autores 
Os dados demonstrados na tabela 19 evidenciam que não basta considerar o efeito tributário (Simples) ao se avaliar a viabilidade de tornar uma atividade informal em formal, até porque, ficou evidenciado, no estudo realizado, que o custo de tributação é menor que as despesas das obrigações acessórias. Por outro lado, também foi possível demonstrar que é possível projetar o quanto é necessário vender para compensar esses novos gastos. Algo que é muito importante, pois como já foi informado, o fato do empreendimento estar na informalidade, o seu mercado é restrito (não tem como fornecer para clientes que exigem documentação) e passando para a formalida- de, certamente, o volume de vendas será bem maior. Cabe avaliar, nesse caso específico, se as vendas serão superiores ou não a 45,58\%. No entanto, mesmo que elas não sejam, é importante considerar que o valor de lucro hoje gerado é de forma informal, representando uma sonegação, já uma vez na formalidade, deixará de existir a infração. Ou seja, além de avaliar o valor da redução de lucro, é necessário avaliar o ganho, em termos legais, ao passar para a formalidade. Outro ponto que se deve considerar, é o fato de que as despesas fixas não variam em função do aumento da venda, ou seja, uma vez paga essa despesa, tudo que é vendido a mais, passa a gerar um lucro maior.

Tabela 20: Percentual necessário para aumento do preço de venda

\begin{tabular}{|c|c|c|}
\hline \multirow{2}{*}{ Valores necessários } & \multicolumn{2}{|l|}{ Situação } \\
\hline & Informal & Formal \\
\hline Lucro líquido final & $1.004,18$ & $1.004,18$ \\
\hline Total das despesas Fixas & - & 300,00 \\
\hline Total dos custos fixos & 40,82 & 40,82 \\
\hline Total da margem de contribuição & $1.045,00$ & $1.345,00$ \\
\hline Custo variável total & $1.646,10$ & $1.646,10$ \\
\hline Total dos valores que não se alteram com o aumento do PV & $2.691,10$ & $2.991,10$ \\
\hline Despesa Variável ( $4,5 \% \mathrm{~s} /$ o preço de venda - faturamento) & - & 140,94 \\
\hline Faturamento necessário para obter o lucro líquido final & $2.691,10$ & $3.132,04$ \\
\hline Aumento necessário no preço de venda & - & $16,39 \%$ \\
\hline
\end{tabular}

Fonte: Produção dos autores

Além de aumentar o lucro em 45,58\% para conseguir a margem necessária para continuar com o lucro atual, existem mais duas maneiras: aumentar o preço de venda ou incluir novos produtos no "mix" de produção. Na tabela 20 é apresentado o percen- tual de aumento que o preço de venda precisa sofrer para manter o lucro atual.

Para determinar este aumento foi necessário determinar o total do lucro líquido atual, acrescido a este valor foram considerados os totais de custos fixos e despesas fixas 
de todos os produtos, assim chegando a uma margem de contribuição total. Para o cálculo do custo variável, conforme já mencionado, em função da empresa se tornar optante pelo Simples Nacional, este custo não sofrerá alteração com a formalidade, por isso manteve-se o mesmo custo. Com isso, foi encontrado os valores que não se alteram com o aumento do preço de venda. Porém, a primeira alternativa (aumento do preço de venda) não é muito viável, pois o aumento seria de 16,39\%. Observa-se, que com o aumento do preço de venda, os custos variáveis não aumentam, porém as despesas variáveis aumentam no mesmo percentual da variação do preço de venda.

Embora, o percentual do aumento do preço de venda $(16,39 \%)$ seja menor que o percentual aumento da produção/venda (45,58\%) é bem mais provável buscar a compensação do custo da formalidade via aumento da produção do que pelo preço de venda, pois o simples argumento da formalização talvez não seja o suficiente para convencer os atuais clientes. Já a segunda alternativa é a mais viável, pois com novos produtos, além de aumentar o faturamento e a margem, a Pão e Biscoito consegue também ter um rateio maior nos custos e despesas fixas agregados a formalidade. A proprietária informou que já estão sendo avaliados novos produtos a serem lançados, dentre eles pode ser destacado: massas e molhos.

Outro ponto muito importante a ser considerado é o fato de que, nesse momento, por ter só um funcionário a Pão e Biscoito, para sair da formalidade, não precisa arcar com os encargos que o Simples Nacional impõe, mas sim optar, nesse primeiro momento pelo EI. Ao optar pelo EI, a Pão e Biscoito deve estar muito atenta as duas condições exigidas para permanecer como EI: ter só um funcionário e o faturamento não ser superior a $\mathrm{R} \$ 5.000,00$. Entre as duas, a que requer uma atenção maior é a primeira, já que ela poderá obrigar a Pão e Biscoito, abrir mão dos benefícios do EI e passar para o Simples Nacional, independente do valor do faturamento. Já a segunda é uma consequência do crescimento, fato esse desejado por qualquer empreendedor. Entende-se que, ao atingir o faturamento de $\mathrm{R} \$ 5.000,00$ seja via aumento de preço ou aumento de produção, desde que mantida ou aumentada a margem dos produtos e sem o aumento significativo das despesas fixas, a Pão e Biscoito não terá nenhuma dificuldade de manter o negócio viável, uma vez que, conforme ficou demonstrado na tabela 20, o faturamento necessário para manter o resultado de hoje, ao optar pelo Simples Nacional é de R\$3.132,04, valor bem inferior ao valor de faturamento $(\mathrm{R} \$ 5.000,00)$ limite de permanecer no EI e passar para o Simples Nacional

Apesar deste momento não ser economicamente viável a formalidade, adotando o sistema Simples Nacional, a mesma é uma alternativa interessante, pois além de sair da informalidade, a opção de tributação pelo Simples Nacional também permitirá que a Pão e Biscoito atue em novos mercados. Sendo assim, é importante analisar que uma redução neste momento no lucro, poderá ser um investimento inicial que irá trazer ganhos maiores no futuro.

\section{Conclusão}

O estudo realizado, além de avaliar a rentabilidade gerada pelos produtos com base na situação atual que a empresa se encontra (informalidade), também avaliou alternativas para que a empresa pudesse migrar para a formalidade e mesmo assim se manter lucrativa. Sendo assim, pode-se dizer que o estudo de caso está dividido em dois momentos.

Analisando a rentabilidade atual e também considerando que a Pão e Biscoito atua em turno parcial, sua origem é familiar, o fato de possuir clientes fiéis e por se tratar de uma empresa na informalidade, o atual retorno 
obtido é bom, visto que, o valor do resultado final é considerado como um bom "pró-labore" pela proprietária, diante do investimento e do tempo despendido. Outra constatação que o estudo pode apurar foi o fato de que, mesmo apresentando uma pequena variedade de produtos, todos eles apresentam rentabilidade positiva. Em quase todos os produtos o custo com maior representatividade é o da matéria-prima, o único item que não se encaixa nessa estatística é o pão de trigo, onde o percentual da mão de obra direta é maior que o material direto. Isso indica que o processo de produção, da maioria dos produtos, não tem muita representatividade no custo final.

A análise da margem de contribuição, lucro e rentabilidade permite concluir que na linha de biscoitos, nos três pontos analisados, o biscoito rosca de milho ocupa o primeiro lugar com o melhor resultado, o biscoito colonial fica em segundo e por último, em terceiro lugar, fica o biscoito caramelado. Isso evidencia quais os produtos que a empresa Pão e Biscoito deveria dar prioridade em sua produção e venda (os que apresentam maior margem de contribuição). Já na linha dos pães, o pão de milho apresenta o melhor resultado, enquanto que o pão de trigo fica em segundo lugar. Essa informação também auxilia a empresa a escolher qual dos dois pães ela deve priorizar, neste caso, o pão de milho. Como esse tipo de pão é pouco explorado pelo mercado em geral, certamente, pode ser um nicho a ser explorado pela empresa.

Além de analisar a atual situação da Pão e Biscoito, foi possível também avaliar a viabilidade do empreendimento tornar-se formal (sair da situação de informalidade em que ele se apresenta atualmente), onde foi evidenciado duas opções: o Empreendedor Individual e a tributação pelo Simples Nacional. Dentre as duas opções estudadas ficou evidenciado que, considerando-se as condições atuais em que a empresa se encontra (faturamento abaixo de cinco mil reais e com apenas um funcionário), a melhor opção para isso é a representada pelo Empreendedor Individual.
No entanto, como já era esperado, para que a empresa pudesse migrar para a formalidade é necessário que ela aceite sacrificar parte de seu resultado.

Após examinar os números, foi possível constatar que no presente momento a opção viável é o EI, onde os impostos e encargos deste enquadramento não impactariam significativamente no resultado da empresa. $\mathrm{Na}$ avaliação do EI pode-se também identificar que, com este enquadramento, além do surgimento da obrigação por pagamento do tributo, também surgem despesas fixas em função dessa migração (despesas com escritório de contabilidade).

Entretanto, a opção do EI, não anula a alternativa do Simples Nacional, no entanto a escolha pelo Simples Nacional só se justificaria se a Pão e Biscoito tivesse um aumento significativo no faturamento, já que o limite máximo de faturamento para permanecer como EI é de cinco mil reais mensais, em média (sessenta mil reais anuais). Superando esse valor, a empresa passa a ser optante do Simples Nacional automaticamente. Considerando que nas duas simulações de aumento de faturamento para compensar os gastos com a formalização pelo Simples Nacional, apresentaram um faturamento inferior a cinco mil reais, é possível concluir que, ao atingir o limite máximo de faturamento exigido para permanecer como EI, a Pão e Biscoito (desde que mantenha as margens atuais e não apresente um aumento das despesas fixas além das projetadas) terá um resultado adicional que permitirá tranquilamente absorver os novos gastos oriundos da exigência do Simples Nacional.

Uma conclusão importante que o estudo evidenciou é que são necessários estudos adequados para identificar qual é a melhor alternativa para migrar um empreendimento da informalidade para a formalidade. No caso apresentado, essa migração seria totalmente inviável se fosse avaliada somente a opção pelo Simples Nacional. No entanto, ao considerar a opção pelo EI, pode-se perceber que ela é uma alternativa viável. 


\section{Referências bibliográficas}

Cervo, A. L., \& Bervian, P. A. (2002). Metodologia científica. 5. ed. São Paulo: Pearson Prentice Hall.

Chér, R. (1990). A gerência das pequenas e médias empresas: o que saber para administrá-las. São Paulo: Maltese.

Crepaldi, S. A. (2002). Contabilidade gerencial: teoria e prática. 2. ed. São Paulo: Atlas.

DIEESE (2011). DIEESE e Sebrae lançam Anuário do Trabalho na Micro e Pequena Empresa. São Paulo. Disponível em: < http:// www.dieese.org.br/anu/anuSebraeMicroPeqEmp/anuarioSebraeRelease.pdf $>$. Acesso em: 11 abr. 2012.

Gil, A. C. (1999). Métodos e técnicas de pesquisa social. 5. ed. São Paulo: Atlas.

Longenecker, J. G., Moore, C. W., \& Petty, J. W. (1998). Administração de pequenas empresas. São Paulo: Makron Books.

Martins, E. (2009). Contabilidade de custos. 9. ed. São Paulo: Atlas.

Padoveze, C. L. (2009). Controladoria es-

tratégica e operacional: conceitos, estrutura, aplicação. 2. ed. São Paulo: Cengage Learning.

Padoveze, C. L. (2003) Curso básico gerencial de custos. São Paulo: Thomson.

Serviço Brasileira de Apoio às Micro e Pequenas Empresas (2005). Boletim estatístico de micros e pequenas empresas. Disponível em <http://201.2.114.147/bds/BDS.nsf/03D E0485DB219CDE0325701B004CBD01/\$F ile/NT000A8E66.pdf> Acesso em: 15 mar. 2012.

Thomé, M. L., \& Costa, C. A. (2008). Análise de fatores condicionantes na adoção de um sistema de custeio em micro e pequenas empresas no setor metal-mecânico de Caxias do Sul-RS. Caxias do Sul, RS. 135 f. : Dissertação (Mestrado). Universidade de Caxias do Sul, Programa de Pós-Graduação em Administração, 2008.

\title{
Procedures for determining and analyzing the profitability of products in small food companies
}

\begin{abstract}
In today's competitive market, knowing the profitability of the products offered is key to the success of a company. However, to reach this percentage must follow certain procedures. Thus, this research conducted aims to highlight the procedures to be followed for determining and analyzing the profitability of products in small food enterprises and to achieve this goal, the study shows a survey of the theoretical framework related to the theme. The research is exploratory typology, performing a case study aiming to analyze the profitability of the company's products and also studied to identify the viability of the company or not become formal. Data gathering was done to monitor all production process of the products studied. With the study concludes that small businesses play a vital role in the Brazilian economy and world, but they must be prepared to survive the hardships of the market. Therefore, the study conducted showed that in the current situation the project has good profitability of their products and to become formal, the best option at the present time, is being Individual Entrepreneur. The other option for taxation becomes favorable only after increased revenue, because with formalizing the company will have some fixed expenses that are not there.
\end{abstract}

Keywords: Micro and small business. Cost accounting. Contribution margin. Profit. Profitability. Viability of formalization. 